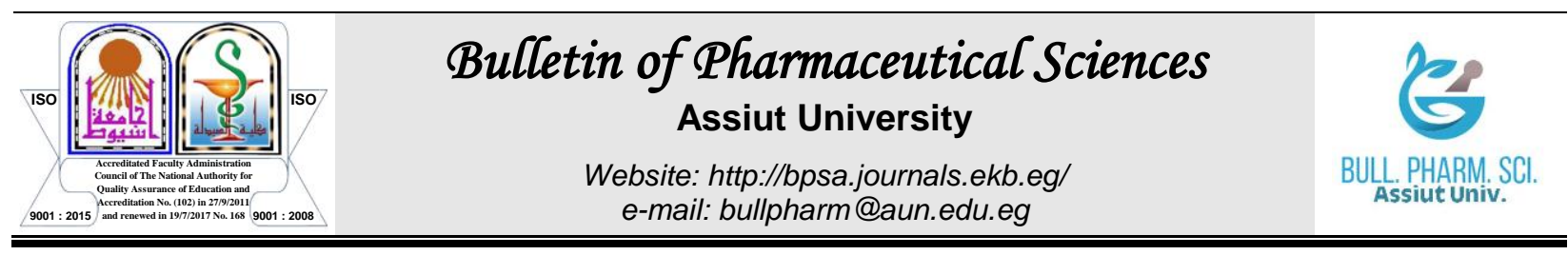

\title{
INTERACTION OF SILDENAFIL WITH HERBAL SUPPLEMENTS: A REVIEW
}

Issam Mohammed Abushammala

\author{
Department of Pharmaceutics and Industrial Pharmacy, Faculty of Pharmacy, Al- Azhar \\ University- Gaza, P.O Box: 1277, Palestine
}

Erectile dysfunction (ED) is defined as a man's inability to achieve or maintain an erection long enough to complete sexual activity. Sildenafil (SILD) is a drug that is used to treat ED all over the world. In this review article, the interactions between SILD and herbal supplements recorded in the literature were summarized using the Medline database (via PubMed) and the key-words: Sildenafil, herbal supplements, and interactions. In the present review article, pharmacokinetic (PK) and pharmacodynamic (PD) interactions were reported during co-administration of herbal supplements with SILD. Reduction in SILD bioavailability was found as a result of interaction of SILD with Horny goat weed, Thai ginseng, Arugula, Black seed, Garden cress, Fenugreek, and Pummelo juice in human and/or animal models. Meanwhile, Citrus lemon juice has not significantly altered the PK of SILD. Also, PD interactions were found as a result of the interaction of Curcumin, Yohimbine, and Pomegranate juice in human and rat models. Healthcare professionals should be aware of this potential and researchers should strive to fill the numerous gaps in our present understanding of this problem.

\section{INTRODUCTION}

Erectile dysfunction is defined as the inability to achieve or maintain an erection long enough to complete sexual activity. It's a complicated condition that's brought on by both physical and psychological factors ${ }^{1 \& 2}$. SILD is a medicine that is used to treat ED all over the world ${ }^{3}$.

SILD is an orally given Phosphodiesterase5 (PDE-5) inhibitor that has been shown to be an effective treatment for male ED caused by organic malfunction, psychological causes, or a combination of causes. Furthermore, SILD has been shown to be very effective in clinical settings, with a broad margin of safety, patient satisfaction, and better quality of life in the majority of patients ${ }^{3-5}$.

SILD is rapidly absorbed after oral administration $^{6}$ and is mainly metabolized by the cytochrome P450 (CYP) hepatic isoenzymes 3A4 (a major pathway) and 2C9 (a minor route) $)^{7}$. CYP450 transforms SILD into an active form of $\mathrm{N}$-desmethyl metabolite which has been found to account for around half of SILD potency and activity. SILD and its metabolite are strongly bound to plasma proteins $(96 \%)$ and have terminal half-lives of 4 hours $^{8}$.

Despite the widespread use of herbal treatments, there are few reported herb-drug interactions, and many of those that have been detected are based on single case reports ${ }^{9}$. Because CYP3A4 plays a key role in the biotransformation of SILD, using medications or herbal treatments that inhibit or induct CYP3A4 at the same time can lead to harmful drug interactions ${ }^{10}$.

Herb-drug interactions may be more common than drug-drug interactions, owing to the fact that pharmaceuticals typically contain single chemical entities, but nearly all medicinal supplements (including single-herb formulations) contain combinations of pharmacologically active ingredients ${ }^{11}$. When a herbal supplement and a drug share a common absorption, distribution, metabolism, or excretion mechanism, the drug's concentration 
at the site of action may be changed. Herb-drug interactions can also form the basis of pharmacodynamic mechanisms, which are characterized by direct pharmacologic activities of an herbal extract that are unrelated to changes in blood concentrations ${ }^{12}$.

Herbal remedies are thought to be safe by the general public because they are natural. This, however, is a dangerous oversimplification. Herbal side effects have been recorded in a variety of ways, including adverse events caused by drug-herb interactions ${ }^{13-15}$.

The purpose of this review article is to provide an overview of the clinical data on herbal supplements and SILD interactions. Herbal supplements and SILD interactions are reviewed, with concrete examples, mechanisms, and other clinical observations. To generate a comprehensive summary of reported interactions between herbal supplements and SILD, an intensive investigation of scientific literature in the PubMed database, Research Gate, Google Scholar, Science Direct, and recent conference papers was undertaken. Table 1 lists the clinical herbal supplements-SILD interactions that have been studied, as well as the level of evidence for each interaction. The overall purpose of this review article is to increase pharmacists' and physicians' understanding of this concern and thereby protect patients' health.

\section{MEDICINAL HERBS AND SILDENAFIL INTERACTIONS}

\section{Horny goat weed}

Horny goat weed (Epimedium sagittatum) is used widely to treat male ED. The principal functions of horny goat weed included the nutrition and reinforcement of the renal viscera, which resulted in the restoration of erectile function in males. The PK profile data in the literature is scarce, and is mostly focused on icariin, the predominant pure product from the horny goat weed species ${ }^{16-18}$.

A PK interaction study conducted in rats was designed to explore dose related interaction between the extract of horny goat weed $(1 / 2 \mathrm{~g} / \mathrm{kg} / \mathrm{day})$ for three consecutive days and intravenous injection with SILD (10/30 $\mathrm{mg} / \mathrm{kg}$ ) SILD. The study demonstrates that there were significant herb-drug interaction between horny goat weed extract and SILD at low and high daily doses, suggesting that coadministration use of horny goat weed extract and SILD in clinical practice should be prevented due to possible herb-drug interactions ${ }^{19}$.

\section{Thai ginseng}

Thai ginseng (Kaempferia parviflora) The medicinal plant Thai ginseng, or Krachaidum, belongs to the Zingiberaceae family. Thai ginseng has been demonstrated to have antiallergenic, anti-inflammatory, antimutagenic, anti-depressive, anticholinesterase, antimicrobial, anticancer, antiulcer, cardioprotective, anti-obesity, and aphrodisiac properties in a variety of pharmacological trials ${ }^{20}$.

In a PK study aimed to investigate the effect of Thai ginseng extract $(250 \mathrm{mg} / \mathrm{kg}$ daily for 9 days) on the PKs of SILD in a random manner, rats were divided into several groups. The findings revealed a strong interaction between Thai ginseng extracts and SILD, resulting in a reduction in the area under the curve (AUC) and maximum concentration $\left(\mathrm{C}_{\max }\right)$ values of SILD respectively ${ }^{21}$. In order to avoid possible therapeutic failure in patients with ED, the interaction between Thai ginseng extract and SILD should be taken into account for clinical practice in order to prevent possible therapeutic failure in the treatment of sexual dysfunction.

\section{Green tea}

Green tea (Camellia sinensis, Theaceae) has been studied for its health advantages in cancer prevention, cardiovascular disease prevention, anti-inflammatory, antibacterial, antiangiogenic, antioxidative, neuroprotective, and cholesterol-lowering activities ${ }^{22}$.

A PK study published by Hegazi 2013 investigated the effect of green tea on the PK profile of SILD in healthy males. Green tea and SILD co-administration increased the extent but not the rate of SILD absorption. It resulted in greater $\mathrm{C}_{\max }$ and $\mathrm{AUC}$, as well as a considerable drop in the elimination rate constant of SILD. Patients who use green tea may require lower SILD doses ${ }^{23}$. 
Table 1: Herbal supplements-SILD interactions.

\begin{tabular}{|c|c|c|c|c|c|}
\hline Herb & $\begin{array}{l}\text { Study } \\
\text { type }\end{array}$ & $\begin{array}{l}\text { Outcome } \\
\text { measures }\end{array}$ & $\begin{array}{l}\text { Effect on PK/PD of } \\
\text { SLD }\end{array}$ & $\begin{array}{l}\text { Mechanism of } \\
\text { interaction }\end{array}$ & References \\
\hline $\begin{array}{l}\text { Horny goat } \\
\text { weed }\end{array}$ & Rats & PK & $\begin{array}{l}\text { Reduction in the } \\
\text { AUC }\end{array}$ & $\begin{array}{l}\text { Induced } \\
\text { CYP3A4 activity }\end{array}$ & $\begin{array}{l}\text { Hsueh et al., } \\
2013(19)\end{array}$ \\
\hline Thai ginseng & Rats & PK & $\begin{array}{l}\text { Reduction in the } \\
\text { AUC and } C_{\max }\end{array}$ & $\begin{array}{l}\text { Induced } \\
\text { CYP3A4 activity }\end{array}$ & $\begin{array}{l}\text { Mekjaruskul } \\
\text { and } \\
\text { Sripanidkulchai } \\
2015 \text { (21) }\end{array}$ \\
\hline Green tea & Human & PK & $\begin{array}{l}\text { Increase in the } \mathrm{C}_{\max } \\
\text { and } A \mathrm{AC}_{0-\infty}, \\
\text { decrease in the ke } \\
\text { and prolonged } \mathrm{t}_{1 / 2}\end{array}$ & $\begin{array}{l}\text { Inhibited } \\
\text { CYP3A4 activity }\end{array}$ & $\begin{array}{l}\text { Hegazi, } 2013 \\
\text { (23) }\end{array}$ \\
\hline Arugula & Rats & PK & $\begin{array}{l}\text { Reduction in the } \mathrm{C}_{\max } \\
\text { and AUC }\end{array}$ & $\begin{array}{l}\text { Induced } \\
\text { CYP3A4 activity }\end{array}$ & $\begin{array}{l}\text { Mallah et al., } \\
2017(26)\end{array}$ \\
\hline Black seed & Dogs & PK & $\begin{array}{l}\text { Reduction of the } \\
\mathrm{C}_{\max }, \mathrm{AUC}_{0-\infty} \text { and } \mathrm{t}_{1 / 2}\end{array}$ & $\begin{array}{l}\text { Induced } \\
\text { CYP3A4 activity }\end{array}$ & $\begin{array}{l}\text { Al-Mohizea et } \\
\text { al., 2015 (31) }\end{array}$ \\
\hline Garden cress & Dogs & PK & $\begin{array}{l}\text { Reduction in the } \mathrm{C}_{\max } \\
\text { and AUC }\end{array}$ & $\begin{array}{l}\text { Induced } \\
\text { CYP3A4 activity }\end{array}$ & $\begin{array}{l}\text { Al-Mohizea et } \\
\text { al., } 2015 \text { (31) }\end{array}$ \\
\hline Fenugreek & Dogs & PK & $\begin{array}{l}\text { Reduction in the } \mathrm{C}_{\max } \\
\text { and AUC }\end{array}$ & $\begin{array}{l}\text { Induced } \\
\text { CYP3A4 activity }\end{array}$ & $\begin{array}{l}\text { Al-Mohizea et } \\
\text { al., } 2015 \text { (31) }\end{array}$ \\
\hline Marijuana & Human & PK & $\begin{array}{l}\text { Increase in the } \mathrm{C}_{\max } \\
\text { and AUC }\end{array}$ & $\begin{array}{l}\text { Inhibited } \\
\text { CYP3A4 activity }\end{array}$ & $\begin{array}{l}\text {. Murtadha et } \\
\text { al., } 2021 \text { (33) }\end{array}$ \\
\hline $\begin{array}{l}\text { Grapefruit } \\
\text { juice }\end{array}$ & Human & PK & $\begin{array}{l}\text { Increase in the } \mathrm{AUC}_{0-} \\
\infty \text { with no change in } \\
\text { the } \mathrm{C}_{\max } \text { and delayed } \\
\text { sildenafil absorption }\end{array}$ & $\begin{array}{l}\text { Inhibited } \\
\text { CYP3A4 activity }\end{array}$ & $\begin{array}{l}\text { Jetter et al., } \\
2002(36)\end{array}$ \\
\hline $\begin{array}{l}\text { Bitter } \\
\text { orange juice }\end{array}$ & Human & PK & $\begin{array}{l}\text { Increase in the } \mathrm{AUC}_{0-} \\
\text {, no change in } \mathrm{t}_{\max }, \\
\text { no change in } \mathrm{t}_{1 / 2} \text { and } \\
\text { reduction in the } \\
\text { apparent oral } \\
\text { clearance }\end{array}$ & $\begin{array}{l}\text { Inhibited } \\
\text { CYP3A4 activity }\end{array}$ & $\begin{array}{l}\text { Abdelkawy et } \\
\text { al., } 2016 \text { (10) }\end{array}$ \\
\hline $\begin{array}{l}\text { Citrus lemon } \\
\text { juice }\end{array}$ & Human & PK & $\begin{array}{l}\text { No significant } \\
\text { alterations in the PK } \\
\text { of sildenafil. }\end{array}$ & $\begin{array}{l}\text { Inhibited } \\
\text { CYP3A4 activity }\end{array}$ & $\begin{array}{l}\text { Abdelkawy et } \\
\text { al., } 2016 \text { (10) }\end{array}$ \\
\hline $\begin{array}{l}\text { Pummelo } \\
\text { juice }\end{array}$ & Human & PK & $\begin{array}{l}\text { Reduction in the } \mathrm{C}_{\max } \\
\text { and } \mathrm{AUC}_{0-\infty}\end{array}$ & $\begin{array}{l}\text { Induced } \\
\text { CYP3A4 activity }\end{array}$ & $\begin{array}{l}\text { Al-Ghazawi et } \\
\text { (43) al., } 2010\end{array}$ \\
\hline Curcumin & Rats & $\mathrm{PD}$ & $\begin{array}{l}\text { Improve in nerve } \\
\text { functions, } \\
\text { biochemical, and } \\
\text { histopathological } \\
\text { parameters }\end{array}$ & $\begin{array}{l}\text { Inhibition of } \\
\text { mitogen protein } \\
\text { kinase and } \\
\text { inhibition of COX-2 } \\
\text { pathways }\end{array}$ & $\begin{array}{l}\text { Kaur et al., } \\
2017 \text { (48) }\end{array}$ \\
\hline Yohimbine & Rats & PD & $\begin{array}{l}\text { A dose-dependent } \\
\text { relaxing effect on rat } \\
\text { corpus cavernosum } \\
\text { strips and an increase } \\
\text { in nitric oxide level } \\
\text { in rats' penis }\end{array}$ & $\begin{array}{l}\text { Alpha-2- } \\
\text { adrenocepor } \\
\text { antagonist may } \\
\text { increased penile } \\
\text { blood flow }\end{array}$ & $\begin{array}{l}\text { Saad et al., } \\
2013(50)\end{array}$ \\
\hline $\begin{array}{l}\text { Pomegranate } \\
\text { juice }\end{array}$ & Human & PD & Low-flow priapism & $\begin{array}{l}\text { Antioxidant effect } \\
\text { might enhanced the } \\
\text { bioavailability of } \\
\text { endothelial nitric } \\
\text { oxide levels }\end{array}$ & $\begin{array}{l}\text { Senthilkumaran } \\
\text { et al., } 2012 \\
\text { (52) }\end{array}$ \\
\hline
\end{tabular}




\section{Arugula}

Arugula (Eruca sativa) The annual herbaceous plant Arugula, sometimes known as

rocket plant (jarjeer), belongs to the Brassicaceae family. Arugula is a garden plant that has been used in traditional medicine to increase male sexual desire ${ }^{24-26}$.

In a crossover experiment with a washout period of two weeks conducted on rats, the $\mathrm{C}_{\max }$ of SILD was increased after Arugula was preadministered. Moreover, when SILD was preadministered to a group of rats with Arugula, the AUC of SILD increased considerably. The results imply that co-administering of Arugula with SILD improves its PK profile in rat plasma. In the presence of Arugula, the concentration of SILD in rat plasma increased substantially. In conclusion, when sexual stimulants were combined with SILD, some care had to be taken ${ }^{26}$.

\section{Black seed, Garden cress, Fenugreek}

Black seed (Nigella sativa) is used to cure and prevent a variety of ailments and conditions, particularly asthma, diarrhea, and dyslipidemia $^{27}$. Black seed has antiinflammatory, analgesic, anti-diabetic, antihyperlipidemic, anti-convulsant, anti-microbial, anti-ulcer, anti-hypertensive, anti-asthmatic, and anti-cancer effects, according to laboratory studies. Antioxidant, immunomodulating, cytoprotective, and an inhibitory effect on certain inflammatory mediators are some of the ways in which it works ${ }^{28}$.

Garden cress (Lepidium sativum) is used for different conditions, such as cough, vitamin $\mathrm{C}$ deficiency, constipation, poor immunity, and as a diuretic. It is useful as a poultice for sprains and for leprosy, skin diseases, dysentery and diarrhea ${ }^{29}$.

Fenugreek (Trigonella foenum-graecum) is an annual crop from the Fabaceae family. Simple alkaloids such as trigonelline, choline, gentianine, carpaine, and saponine are the most prominent ingredients. Fenugreek has been shown to have anti-diabetic, anti-cancer, antibacterial, anti-parasitic, and cholesterol lowering properties ${ }^{30}$.

Al-Mohizea and partners investigated the effects of Black seed, Garden cress and Fenugreek (pretreated for one week) on the PK of orally administered SILD using beagle dogs (100 mg for each).

Black seed reduced the AUC, $\mathrm{C}_{\max }$, and half-life $\mathrm{t}_{1 / 2}$ of SILD, whereas Garden cress and Fenugreek decreased the $\mathrm{C}_{\max }$ and AUC of SILD dramatically after co-administration. Furthermore, it was observed that taking any of the explored herbs with SILD at the same time had an effect on its PKs. The use of researched herbs in combination should be done with caution, since it may lower SILD bioavailability ${ }^{31}$.

\section{Marijuana}

Marijuana (Cannabis) has been used for the relief of pain and seizures. It contains more than 100 natural compounds that have been identified as phytocannabinoids ${ }^{32}$. In a human study, healthy participants were randomly assigned to one of three groups: nonsmokers, cigarette smokers, and Marijuana users. In the cigarette smokers' group, the $\mathrm{AUC}_{0-\mathrm{t}}$ of SILD $(50 \mathrm{mg})$ revealed a statistically significant increase, whereas in the non-smokers group, there was a non-significant increase. Furthermore, among cigarette smokers and Marijuana users, the $\mathrm{C}_{\max }$ of SILD also increased respectively ${ }^{33}$. Cigarette smoking significantly enhances SILD exposure while having no influence on its pharmacodynamics, safety, or tolerance.

\section{Grapefruit juice}

Grapefruit juice (Citrus paradisi Macfad) inhibits the $\mathrm{P}$-glycoprotein (P-gp) pump and changes the PKs of several drugs by blocking various enzyme systems, resulting in enhanced bioavailability $^{34 \& 35}$. The bioavailability of SILD was increased in a randomized crossover study in which male volunteers received a single 50 mg dose of SILD when co-administered with Grapefruit juice. Although patients are unlikely to be harmed if they take Grapefruit juice at the same time, it is prudent to avoid this combination $^{36}$.

\section{Bitter orange and Citrus lemon}

Citrus fruits and drinks are widely consumed around the world due to their purported health benefits, primarily antioxidative and anti-proliferative properties. Fruit juice-drug interactions have received a lot of attention in clinical practice. Bitter orange 
juice (Seville orange), one of the common varieties of the Citrus aurantium species. Bitter orange juice has been utilized as an ingredient in dietary supplements and promoted as a weight loss aid ${ }^{37-39}$.

An open-label, crossover study in nine healthy male healthy male volunteers found that Bitter orange juice increased the $\mathrm{AUC}_{0-}$ $\infty$ and $\mathrm{C}_{\max }$ of SILD by $44 \%$ and $18 \%$ respectively without affecting the time to reach peak plasma concentration $\mathrm{t}_{\max }$. Also, Bitter orange juice significantly reduced the clearance of SILD by $30 \%$ without affecting $\mathrm{t}_{1 / 2}$. In the contrast, Citrus lemon juice (lemon juice) did not cause any significant changes in the PKs of SILD. The enhancement of SILD bioavailability by Bitter orange juice may be related to the inhibition of intestinal CYP3A4 and/or P-gp. On the other hand, Citrus lemon juice had no effect on the PK profile of SILD ${ }^{10}$. Further investigations are necessary to confirm the obtained results.

\section{Pummelo juice}

Pummelo (Citrus grandis) is an exotic large citrus fruit that is an ancestor of the common grapefruit. It was found that Pummelo has different PK interactions when coadministered with specific medications. However, Pummelo was shown to augment the bioavailability of tacrolimus, cyclosporine, and felodipine felodipine ${ }^{40-42}$. In a randomized, twoperiod, two-treatment, two-sequence, single dose, crossover clinical study, the impact of Pummelo juice on the PKs of SILD (equivalent to $50 \mathrm{mg}$ ) in healthy male participants in fasting conditions was investigated and compared to water as a control. The study results showed that Pummelo juice led to a reduction in the bioavailability by $60 \%$ of SILD So, patients should avoid consuming Pummelo juice before or after administering SILD ${ }^{43}$.

\section{Curcumin}

Curcumin (Curcuma longa) is one of the most well studied functional foods. Curcuma longa and Curcuma domestica, both Zingiberaceae members, are widely cultivated in Asia's tropical regions ${ }^{44 \& 45}$. Curcumin has anti-inflammatory, anti-mutagenic, antibacterial, and anticancer properties. Neuropathic pain associated with chronic alcohol intake is a bothersome problem that affects both the central and peripheral nerve systems and has no satisfactory treatment to date ${ }^{46 \& 47}$. In a study on alcohol-induced neuropathic pain in rats, the combination of Curcumin and SILD was found to have a protective effect. Curcumin and SILD coadministered by the intraperitoneal route (i.p.) of administration were found to increase nerve function considerably. As a result, it is postulated that employing Curcumin and SILD together could add a new dimension to the treatment of alcohol-induced neuropathic pain that affects both the central and peripheral nerve systems ${ }^{48}$.

\section{Yohimbine}

Yohimbine (Pausinystalia johimbe) is the major alkaloid found in the stem bark of yohimbe, Pausinystalia johimbe (Rubiaceae). In rats, the effects of Yohimbine hydrochloride $(0.2 \mathrm{mg} / \mathrm{kg}$, i.p. $)$ and sildenafil citrate $(20$ $\mathrm{mg} / \mathrm{kg}$, i.p) on cold stress-induced ED were investigated. Yohimbine and SILD were given to rats for 14 days consecutively, 1 hour before the stress session, to see if they had any effect. The results demonstrated that both Yohimbine and SILD have a dose-dependent vasorelaxant action on rat corpus cavernosum strips, which is supported by SILD's rise in nitric oxide levels in rats' penis ${ }^{49 \& 50}$.

\section{Pomegranate juice}

Fruit juice-drug interaction has received wide attention with numerous scientific and clinical investigations ${ }^{51}$. One report found a link between pomegranate juice (Punica granatum) and SILD and the development of low-flow priapism, an emergency case that necessitates rapid medical intervention to avoid complications and the danger of impotence. Researchers also suggested that patients taking SILD should be aware of this potential interaction and cautioned against concurrent use in the future. In the meantime, the manufacturers should be asked to include this in the patient information leaflet. Also, clinicians and practitioners should be aware of this interaction while treating and prescribing SILD $^{52}$. 


\section{CONCLUSION}

Herbal supplements can interact with prescription drugs, which may lead to major clinical repercussions. In these kinds of interactions, both PK and/or PD mechanisms have been proposed to play an important role. Although the underlying mechanisms for the altered drug effects and/or concentrations of concomitant herbal medicines are yet to be determined. Despite the highly use of herbal remedies, there are few documented herb-drug interactions.

Based on a PKs perspective, SILD bioavailability was found to be altered by induction and or inhibition of CYP3A4 in conducted PK interaction studies between the mentioned herbal supplements and SILD in human and/or animal models. Furthermore, PD interactions were found as a result of the interaction of Curcumin, Yohimbine, and Pomegranate juice in human and rat models as shown in table 1.

Herb-drug interactions may be beneficial by enhancing the efficacy and reducing the toxicities of the co-administered drugs. However, herb-drug interactions may increase toxicity or even be fatal. Thus, more studies are needed to confirm and assess the clinical significance of these potential herb-drug interactions. Herb-drug interactions are a reality and can present a serious threat to human health. Healthcare professionals should be aware of this potential and researchers should strive to fill the numerous gaps in our present understanding of this problem.

\section{Acknowledgmnt}

The author wishes to express his deepest gratitude and thanks to all the staff in the Faculty of Pharmacy at Al-Azhar UniversityGaza for their kind support.

\section{REFERENCES}

1. T. F. Lue, "Erectile Dysfunction", $\boldsymbol{N}$ Engl J Med, 342, 1802-1813 (2000).

2. W. Ludwig and M. Phillips, "Organic Causes of Erectile Dysfunction in Men Under 40", Urol Int, 92, 1-6 (2014).

3. K. M. Hosny, N. A. Alhakamy, M. A. Almodhwahi, M. Kurakula, A. M. Almehmady and S. S. Elgebaly, "Self-
Nanoemulsifying System Loaded with Sildenafil Citrate and Incorporated within Oral Lyophilized Flash Tablets: Preparation, Optimization, and In Vivo Evaluation", Pharmaceutics, 12, 1124 (2020).

4. J. D. Corbin, S. H. Francis and D. J. Webb, "Phosphodiesterase Type 5 as a Pharmacologic Target in Erectile Dysfunction", Urology, 60, 4-11 (2002).

5. G. J. Muirhead, M. B. Wulff, A. Fielding, D. Kleinermans and N. Buss, "Pharmacokinetic Interactions between Sildenafil and Saquinavr/Ritonavir", $\boldsymbol{B r} \boldsymbol{J}$ Clin Pharmacol, 50, 99-107 (2000).

6. Y. Wang, M. S. Chow and Z. Zuo, "Mechanistic analysis of $\mathrm{pH}$ dependent solubility and trans-membrane permeability of amphoteric compounds: application to sildenafil". Int J Pharm, 352, 217-224 (2008).

7. K. E. Follman, M. E. Morris, "SimulationBased Analysis of the Impact of Renal Impairment on the Pharmacokinetics of Highly Metabolized Compounds," Pharmaceutics 11(3), 105 (2019).

8. L. Loprete, C. Leuratti, V. Frangione and M. Radicioni, "Pharmacokinetics of a Novel Sildenafil Orodispersible Film Administered by the Supralingual and the Sublingual Route to Healthy Men", Clin. Drug Investig., 38, 765-772 (2018).

9. Z. Hu, X. Yang, P. C. Ho, S. Y. Chan, P. W. Heng, E. Chan, W. Duan, H. L. Koh and S. Zhou, "Herb-drug interactions: a literature review", Drugs, 65(9), 12391282 (2005).

10. K. S. Abdelkawy, A. M. Donia, R. B. Turner and F. Elbarbry, "Effects of Lemon and Seville Orange Juices on the Pharmacokinetic Properties of Sildenafil in Healthy Subjects", Drugs $\boldsymbol{R} \boldsymbol{D}, 16,271$ 278 (2016).

11. A. Fugh-Berman and E. Ernst, "Herb-drug interactions: review and assessment of report reliability", Br J Clin Pharmacol, 52, 587-595 (2001).

12. G. N. Asher, A. H. Corbett and R. L. Hawke, "Common Herbal Dietary 
Supplement-Drug Interactions", Am Fam Physician, 96, 101-107 (2017).

13. S. F. Zhou, Z. W. Zhou, C. G. Li, X. Chen, $\mathrm{X}$. Yu, C. C. Xue and A. Herington,"Identification of drugs that interact with herbs in drug development", Drug Discov Today, 12, 664-673 (2007).

14. D. A. Kennedy and D. Seely, "Clinically based evidence of drug-herb interactions: a systematic review", Expert Opin Drug Saf, 9, 79-124 (2010).

15. A. A. Izzo and E. Ernst, "Interactions between herbal medicines and prescribed drugs: an updated systematic review", Drugs, 69, 1777-1798 (2009).

16. H. Ma, X. He, Y. Yang, M. Li, D. Hao and Z. Jia "The genus Epimedium: an ethnopharmacological and phytochemical review", J Ethnopharmacol, 134, 519-541 (2011).

17. S. Cheng, F. Qiu, S. Wang and J. He "HPLC analysis and pharmacokinetics of icariin in rats", J Sep Sci, 30, 1307-1312 (2007).

18. P. Shen, S. P. Wong, J. Li and E. L. Yong "Simple and sensitive liquid chromatography-tandem mass spectrometry assay for simultaneous measurement of five Epimedium prenylflavonoids in rat sera", $\boldsymbol{J}$ Chromatogr B, 877, 71-78 (2009).

19. T. Y Hsueh, Y. T. Wu, L. C. Lin, A. W. Chiu, C. H. Lin and T. H. Tsai "Herb-drug interaction of Epimedium sagittatum (Sieb. et Zucc.) maxim extract on the pharmacokinetics of sildenafil in rats", Molecules, 18(6), 7323-7335 (2013).

20. S. Saokaew, P. Wilairat, P. Raktanyakan, et al., "Clinical Effects of Krachaidum (Kaempferia parviflora): A Systematic Review", J Evid Based Complementary Altern Med, 22, 413-428 (2017).

21. C. Mekjaruskul and B. Sripanidkulchai, "Pharmacokinetic interaction between Kaempferia parviflora extract and sildenafil in rats", J Nat Med, 69, 224231(2015).

22. S. M. Chacko, P. T. Thambi, R. Kuttan, I. Nishigaki, "Beneficial effects of green tea: a literature review", Chin Med, 5, 13 (2010).

23. S. Hegazy, "The Effect of Green Tea on Sildenafil Pharmacokinetics in Egyptian Healthy Volunteers," Br. J. Pharm. Res., 4, 289-300 (2014).

24. N. S. Jaafar and I. S. Jaafar, "Eruca sativa Linn.: pharmacognostical and pharmacological properties and pharmaceutical preparations", Asian $J$ Pharm Clin Res, 12, 39-45 (2019).

25. N. Altwaijry, T. A. El-Masry, B. Alotaibi, E. Tousson and A. Saleh, "Therapeutic effects of rocket seeds (Eruca sativa L.) against testicular toxicity and oxidative stress caused by silver nanoparticles injection in rats," Environmental Toxicology., 35, 952- 960 (2020).

26. E. Mallah, S. Saleh, W. A. Rayyan, W. A. Dayyih, F. D. Elhajji, M. Mima, R. Awad and T. Arafat, "The influence of Eruca sativa (Arugula) on pharmacokinetics of Sildenafil in rats", Neuro Endocrinol Lett, 38, 295-300 (2017).

27. B. H. Ali and G. Blunden, "Pharmacological and toxicological properties of Nigella sativa," Phytother Res., 17, 299-305 (2003).

28. E. Z. Dajani, T. G. Shahwan and N. E. Dajani, "Overview of the preclinical pharmacological properties of Nigella sativa (black seeds): a complementary drug with historical and clinical significance", J Physiol Pharmacol, 67, 801-817 (2016).

29. B. R. Moser, S. N. Shah, J. K. WinklerMoser, S. F. Vaughn and R. L. Evangelista, "Composition and physical properties of cress (Lepidium sativum L.) and field pennycress (Thlaspi arvense L.) oils", Ind Crops Prod, 30, 199-205 (2009).

30. F. M. Al-Ajmi, "The effect of fenugreek on the bioavailability of glibenclamide in normal beagle dogs", Afr J Pharm Pharmacol., 5, 671-677 (2011).

31. A. M. Al-Mohizea, A. Ahad, G. M. ElMaghraby, F. I. Al-Jenoobi, K. M. AlKharfy, S. A. Al-Suwayeh, "Effects of 
Nigella sativa, Lepidium sativum and Trigonella foenum-graecum on sildenafil disposition in beagle dogs", Eur J Drug Metab Pharmacokinet, 40, 219-224 (2015).

32. M. R. Amin and D. W. Ali, "Pharmacology of Medical Cannabis", Adv Exp Med Biol, 1162,151-165 (2019).

33. M. Murtadha, A. M. Raslan, S. F. Fahmy, N. A. Sabri, "Changes in the Pharmacokinetics and Pharmacodynamics of Sildenafil in Cigarette and Cannabis Smokers", Pharmaceutics, 13, 876 (2021).

34. J. Kiani and S. Z. Imam, "Medicinal importance of grapefruit juice and its interaction with various drugs", Nutr $J$, 6(33), 33 (2007).

35. D. G. Bailey, G. Dresser and J. M. Arnold, "Grapefruit-medication interactions: Forbidden fruit or avoidable consequences?", CMAJ, 185, 309-316 (2013).

36. A. Jetter, M. K. Schippers, M.W. Bonjean, U. Hering, J. Bulitta, P. Schreiner, F. Sörgel and U. Fuhr, "Effects of grapefruit juice on the pharmacokinetics of sildenafil", Clin Pharmacol Ther, 71, 2129 (2002).

37. M. J. Hanley, P. Cancalon, W. W. Widmer and D. J. Greenblatt, "The effect of grapefruit juice on drug disposition", Expert Opin Drug Metab Toxicol, 7, 267286 (2011).

38. S. Haaz, K. R. Fontaine, G. Cutter, et al, "Citrus aurantium and synephrine alkaloids in the treatment of overweight and obesity: an update", Obes Rev, 7, 7988 (2006).

39. S. J. Stohs, H. G. Preuss and D. Bagchi, "Bitter orange, ephedra, and hydroxycitric acid: issues with the article "Dietary supplements for improving body composition and reducing body weight: where is the evidence", Int J Sport Nutr Exerc Metab, 22, 407-410 (2012).

40. K. Egashira, H. Ohtani, S. Itoh, N. Koyabu, M. Tsujimoto, H. Murakami and Y. Sawada, "Inhibitory effects of pomelo on the metabolism of tacrolimus and the activities of CYP3A4 and Pglycoprotein", Drug Metab Dispos, 32, 828-833 (2004).

41. J. Grenier, C. Fradette, G. Morelli, G. J. Merritt, M. Vranderick and M. P. Ducharme, " Pomelo juice, but not cranberry juice, affects the pharmacokinetics of cyclosporine in humans", Clin Pharmacol Ther, 79, 255262 (2006).

42. L. Q. Guo, Q. Y. Chen, X. Wang, Y. X. Liu, X. M. Chu, X. M. Cao, J. H. Li and Y. Yamazoe, "Different roles of pummelo furanocoumarin and cytochrome $\mathrm{P} 450$ $3 \mathrm{~A} 5 * 3$ polymorphism in the fate and action of felodipine", Curr Drug Metab., 8, 623-630 (2007).

43. M. A. Al-Ghazawi, M. S. Tutunji and S. M. AbuRuz, "The effects of pummelo juice on pharmacokinetics of sildenafil in healthy adult male Jordanian volunteers.

Eur J Clin Pharmacol, 66, 159-163 (2010).

44. T. Tsuda, "Curcumin as a functional foodderived factor: degradation products, metabolites, bioactivity, and future perspectives," Food Funct., 9, 705-714 (2018).

45. S. C. Gupta, B. Sung, J. H. Kim, S. Prasad, S. Li and B. B. Aggarwal, "Multitargeting by turmeric, the golden spice: from kitchen to clinic", Mol Nutr Food Res, 57, 1510-1528 (2013).

46. B. B. Aggarwal, A. Kumar and A. C. Bharti, "Anticancer potential of curcumin: Preclinical and clinical studies", Anticancer Res, 23, 363-398 (2003).

47. M. L. Lestari and G. Indrayanto, "Curcumin. Profiles Drug Subst," Excip. Relat. Methodol, 39, 113-204 (2014).

48. M. Kaur, A. Singh, B. Kumar, S. K. Singh, A. Bhatia, M. Gulati, T. Prakash, P. Bawa and A. H. Malik, "Protective effect of co-administration of curcumin and sildenafil in alcohol induced neuropathy in rats", Eur J Pharmacol, 15, 58-66 (2017).

49. V. Raman, B. Avula, A. M. Galal, Y. H. Wang and I. A. Khan, "Microscopic and UPLC-UV-MS analyses of authentic and 
commercial yohimbe (Pausinystalia johimbe) bark samples," J Nat Med., 67, 42-50. (2013).

50. M. A. Saad, N. I. Eid, H. A. Abd El-Latif and H. M. Sayed, "Potential effects of yohimbine and sildenafil on erectile dysfunction in rats", Eur J Pharmacol, 30, 127-133 (2013).
51. N. R. Srinivas, "Is pomegranate juice a potential perpetrator of clinical drug-drug interactions? Review of the in vitro, preclinical and clinical evidence", Eur $\boldsymbol{J}$ Drug Metab Pharmacokinet, 38, 223-229 (2013).

52. S. Senthilkumaran, N. Balamurugan, P. Suresh and

Thirumalaikolundusubramanian, $\mathrm{P}$ Priapism, pomegranate juice, and sildenafil: Is there a connection?", Urol Ann, 4, 108-110 (2012). 


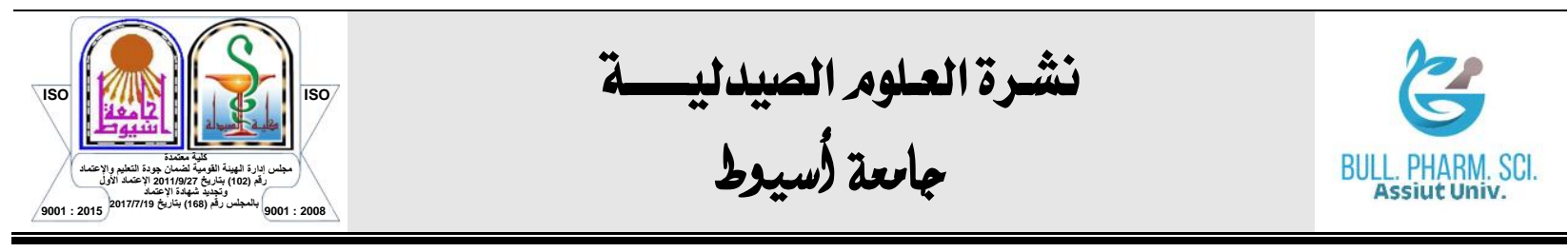

\section{تفاعل السيلاينافيل مع المكملات العثبية: مراجعة \\ عصام محمد أبو شمالة}

قسم الصيدلانيات والصيدلة الصناعية ، كلية الصيدلة ، جامعة الأزهر ، غزة ، فلسطين صندوق بريد ITYY

يُعرَّ ضعف الانتصاب بعدم قدرة الرجل على تحقيق الانتصاب أو الحفاظ عليه لفترة كافيـة

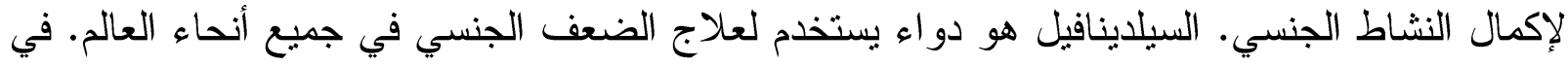

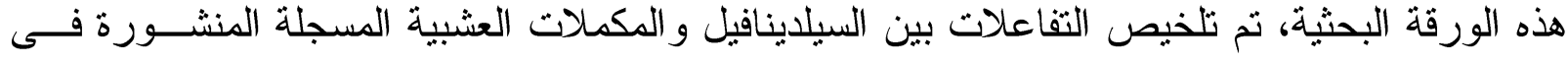
مجلات عالمية باستخدام قاعدة بيانات Medline (عبر PubMed) و الكلمـات الرئيســية: الســـيلدينافيل

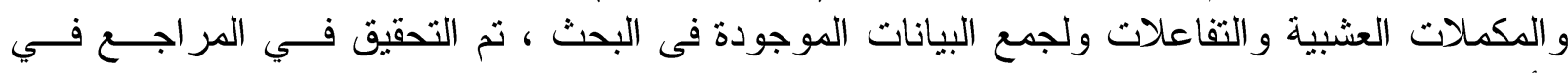

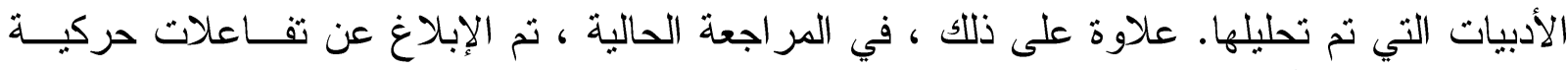

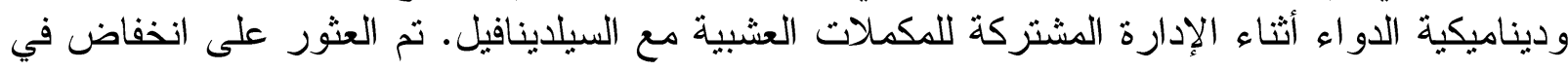

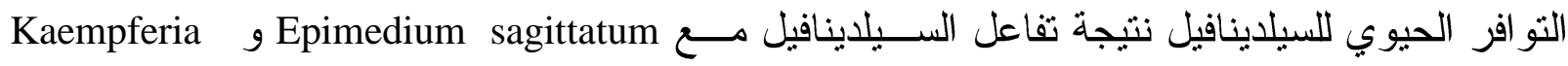

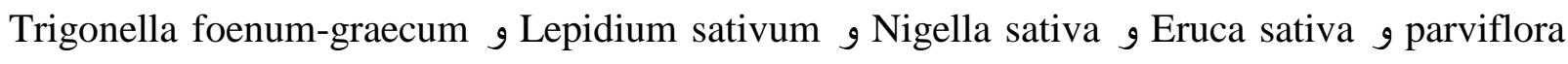

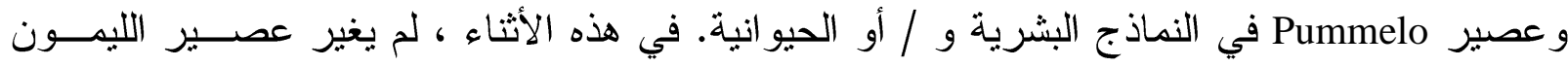

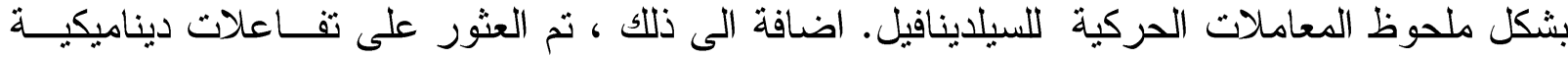

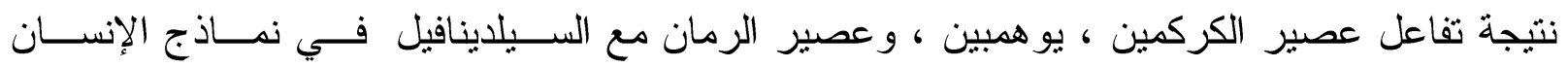

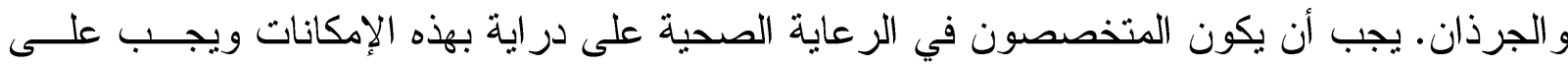
الباحثين السعي لسد الفجوات العديدة في فهمنا الحالي لهذه المشكلة و العمل على لتهن تجنها. 